\title{
Comparison of intravitreal ranibizumab and bevacizumab treatment for retinopathy of prematurity
}

\author{
Comparação de ranibizumab e bevacizumab intravítreos no tratamento da retinopatia da prematuridade
}

Muhammet Kazim Erol ${ }^{1}$, Deniz Turgut Coban ${ }^{1}$, Esin Sogutlu Sarl ${ }^{2}$, Ahmet Burak Bilgin³${ }^{3}$, Berna Dogan ${ }^{1}$, Ozdemir Ozdemir4, Zuhal Ozen Tunay ${ }^{4}$

\section{ABSTRACT}

Purpose: To compare the efficacy of intravitreal ranibizumab and bevacizumab treatment for type 1 retinopathy of prematurity (ROP)

Methods: 36 eyes of 20 patients with type 1 ROP who received anti-vascular endothelial growth factor (anti-VEGF) intravitreal injections between August 2011 and February 2013 were retrospectively evaluated. Fifteen eyes of 8 patients received $0.25 \mathrm{mg}$ ranibizumab (group 1), and 21 eyes of 12 patients received $0.625 \mathrm{mg}$ bevacizumab (group 2). Eyes were examined by indirect ophthalmoscopy on the first day, third day, first week, and first month and as required after injections. Laser photocoagulation was performed in cases with progression of ROP.

Results: The mean gestation time was $26.2 \pm 2.7$ weeks in group 1 patients and $27.1 \pm 2.5$ weeks in group 2 patients. No statistical difference in the time of gestation was observed between the two groups. The mean follow-up period was $20 \pm 4.5$ months. Laser photocoagulation was performed in 6 of 15 eyes from group 1 and 2 of 21 eyes from group 2. No eyes developed retinal detachment during the follow-up period.

Conclusion: Ranibizumab and bevacizumab showed an efficacy in the treatment of type 1 ROP. The incidence of disease relapse was higher in eyes which received ranibizumab. Further randomized, controlled clinical trials are required to compare the efficacy of ranibizumab and bevacizumab.

Keywords: Retinopathy of prematurity; Vascular endothelial growth factor A; Antibodies, monoclonal; Angiogenesis inhibitors; Intravitreal injections

\section{RESUMO}

Objetivo: Comparar a eficácia de ranibizumab e bevacizumab intravítreos no tratamento da retinopatia da prematuridade $(R O P)$ tipo 1.

Método: Foram avaliados retrospectivamente 36 olhos de 20 pacientes com retinopatia da prematuridade tipo 1 que receberam injeções intravítreas anti fator de crescimento endotelial vascular (anti VEGF) entre agosto de 2011 e fevereiro 2013. Quinze olhos de 8 pacientes receberam 0,25 mg ranibizumab (grupo 1) e 21 olhos de 12 pacientes receberam $0,625 \mathrm{mg}$ bevacizumab (grupo 2). Os olhos foram examinados por oftalmoscopia indireta no primeiro dia, terceiro dia, primeira semana, e primeiro mês e conforme necessário após a injeção. Fotocoagulação com laser foi realizada quando foi detectada progressão da retinopatia da prematuridade.

Resultados: Média do tempo de gestação para os pacientes do grupo 1 foi de 26,2 $\pm 2,7$ semanas, enquanto para o grupo 2 foi de $27,1 \pm 2,5$ semanas. Não houve diferença estatística em relação ao tempo de gestação entre os grupos. A média de acompanhamento foi de $20 \pm 4,5$ meses. Fotocoagulação a laser foi realizada a 6 dos 15 olhos do grupo 1 e 2 dos 21 olhos do grupo 2. Nenhum dos olhos desenvolveu descolamento de retina no período de acompanhamento.

Conclusão: $O$ ranibizumab e bevacizumab são eficazes no tratamento da retinopatia da prematuridade tipo 1. Incidência de progressão foi maior nos olhos que receberam ranibizumab. Ensaios clínicos controlados futuros são necessários para comparar esses dois medicamentos.

Descritores: Retinopatia da prematuridade; Fator de crescimento do endotélio vascular; Anticorpos monoclonais; Inibidores da angiogênese; Injeções intravítreas

\section{INTRODUCTION}

Retinopathy of prematurity (ROP) is a potentially blinding disorder in preterm infants characterized by the presence of immature blood vessels. ROP is one of the most important causes of blindness in developing countries ${ }^{(1)}$. The reported incidence of ROP is 16\%-48\% in babies with a birth weight of less than $1000 \mathrm{~g}$ and $27 \%-35 \%$ in babies with a birth weight under $1500 \mathrm{~g}^{(2)}$. ROP is a two-staged disease. In the first stage, all vessel formation ceases because of hyperoxia, with vasoproliferation occurring in the latter stage ${ }^{(3)}$.

The Early Treatment for Retinopathy of Prematurity (ETROP) study demonstrated that earlier treatment in carefully selected cases results in an overall improved visual outcome and posited novel guidance for ROP treatment. According to ETROP, all cases of type 1 disease, zone I ROP with plus disease, zone I stage ||| ROP, and zone || stage 2-3 with plus disease should be treated ${ }^{(4)}$.

A previous study reported significantly increased vitreal vascular endothelial growth factor (VEGF) levels in ROP patients. In the same study, an excess production of VEGF was shown to play an important role in ROP pathogenesis ${ }^{(5)}$. In the Bevacizumab Eliminates the Angiogenic Threat of Retinopathy of Prematurity (BEAT-ROP) study, bevacizumab treatment was found to be more effective than laser photocoagulation for ROP treatment, particularly in patients with zone 1 and 2 posterior disease ${ }^{(6)}$. Moreover, other anti-VEGF therapies, macugen and ranibizumab, demonstrated efficacy in the treatment of ROP when used alone or in combination with laser photocoagulation $^{(7-9)}$. 
The present study aimed to compare the efficacy and reliability of two anti-VEGF agents, ranibizumab and bevacizumab, in the treatment of ROP.

\section{METHODS}

The medical charts of 422 patients screened for ROP between August 2011 and February 2013 in Antalya Training and Research Hospital were retrospectively evaluated. Twenty patients who received anti-VEGF treatment as first-line monotherapy were included in the present study. The study was conducted according to the Declaration of Helsinki, and informed consent was obtained from the parents of all patients. The study was approved by local ethic committee of Zekai Tahir Burak Hospital, Ankara, Turkey. Cases of type 1 disease, zone I ROP with plus disease, zone I stage III ROP, and zone II stage 2-3 with plus disease were classified according to ETROP(10).

We provided detailed information to the parents of patients regarding single-dose ranibizumab and single-dose bevacizumab separately. Intravitreal injections were performed according to parent decisions. Parents with higher socioeconomic status elected to use ranibizumab because it was specifically developed for the treatment of eye disease. Parents with a lower socioeconomic status chose bevacizumab because it is cheaper.

Group 1 included patients in whom ranibizumab was used as the first-line therapy and group 2 included patients who received bevacizumab. Gestational weeks, birth weight, intubation period, maximum oxygen saturation, systemic disorders, and ROP relapse during the follow-up period were compared between the two groups. Post menstrual age (PMA) on initial treatment, relapse, and number of laser shots performed were also compared.

Intravitreal injections were performed under local anesthesia after installation of povidone iodine, eyes were draped, and lid specula were inserted. Injections were performed at $1.5 \mathrm{~mm}$ from the limbus with a 30-gauge needle. Fundoscopic examination was performed after all injections, controlling for central retinal artery flow, cataracts, and retinal tear formation. Netilmicin eye drops were prescribed four times per day for 10 days. The dose of ranibizumab was half the typical adult dose $(0.25 \mathrm{mg})$. The bevacizumab dose was $0.625 \mathrm{mg}$. Fundoscopic examinations were performed on the first day, third day, first week, and first month and as required until vascularization was completed or laser spot scarring had occurred. All exams were performed with indirect ophthalmoscopy and a $28 \mathrm{D}$ lens. In cases of relapse, confluent laser photocoagulation was performed under sedation anesthesia. Relapse was defined as increased arterial tortuosity and venous dilation, formation of retinal neovascularization, and stage III ROP. In addition, cases with membrane formation extending into the vitreous from the retina underwent laser treatment.

Statistical analyses were performed using SPSS 13 program with Mann-Whitney $U$ test, Fisher's exact test and two sample t-tests used to compare groups. P-values less than 0.05 were considered statistically significant.

\section{RESULTS}

Intravitreal anti-VEGF injections were administered to 36 eyes of 20 patients as first treatment. Fifteen eyes of 8 patients ( 4 males, 4 females) received ranibizumab injections in group 1. In group 2, 21 eyes of 12 patients ( 5 males, 7 females) received bevacizumab (Figures 1,2). The mean gestational time was $26.2 \pm 2.7$ weeks in group 1 and $27.1 \pm 2.5$ weeks in group 2 . The mean birth weight was $853 \pm$ $120 \mathrm{~g}$ in group 1 and $925 \pm 110 \mathrm{~g}$ in group 2 (Table 1). The mean post menstrual age (PMA) at the time of injection was $34.4 \pm 1.8$ weeks in group 1 and $35.3 \pm 1.7$ weeks in group 2 (Table 2). Intravitreal anti-VEGF injection was not administered to one eye of one patient in group 1 and three fellow eyes of three patients in group 2 because no progression to type 1 ROP was observed, and ROP had regressed in 1 week in the three fellow eyes of three patients in group 2.
No statistical difference in risk factors, such as sepsis, intraventicular hemorrhage, intubation period, bronchopulmonary dysplasia, and necrotizing enterocolitis, were observed between the groups ( $P>0.05$; Table1).

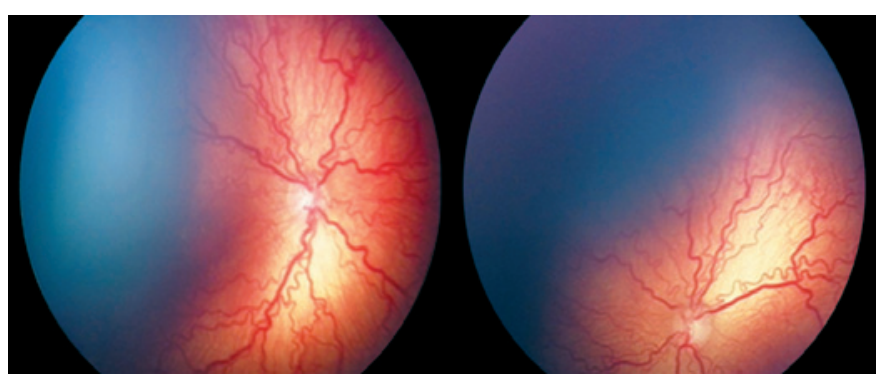

Figure 1. Right and left eyes of a premature baby born at 28 weeks with a $910 \mathrm{~g}$ birth weight.



Figure 2. One year after IV bevacizumab injection in the same patient shown in figure 1.

Table 1. Patient demographics and risk factors

\begin{tabular}{lccc}
\hline & $\begin{array}{c}\text { Ranibizumab } \\
\text { (group 1) } \\
\mathbf{8} \text { infants }\end{array}$ & $\begin{array}{c}\text { Bevacizumab } \\
\text { (group 2) } \\
\text { 12 infants }\end{array}$ & P-value \\
\hline Zone 1 ROP & 10 eyes & & 0.41 \\
Zone 2 ROP & 5 eyes & 9 eyes & 0.72 \\
Male gender & 4 & 5 & 0.53 \\
Gestational time (weeks) & $26.2 \pm 2.7$ & $27.1 \pm 2.5$ & 0.83 \\
Birth weight (kg) & $853 \pm 120$ & $925 \pm 110$ & 0.97 \\
Sepsis (n) & 4 & 7 & 0.65 \\
Intraventricular hemorrhage (n) & 3 & 5 & 0.50 \\
Necrotizing enterocolitis (n) & 5 & 5 & 0.65 \\
Intubation (n) & 7 & 9 & 0.46 \\
APROP & 1 & 1 & $\mathrm{NA}$ \\
\hline
\end{tabular}

$\mathrm{APROP}=$ aggressive posterior $\mathrm{ROP} ; \mathrm{NA}=$ not applied.

Table 2. Mean gestational age at the time of injection

\begin{tabular}{|c|c|c|c|}
\hline & $\begin{array}{c}\text { Ranibizumab } \\
\text { (group 1) }\end{array}$ & $\begin{array}{l}\text { Bevacizumab } \\
\text { (group 2) }\end{array}$ & \\
\hline & 8 infants & 12 infants & P-value \\
\hline $\begin{array}{l}\text { Eyes that received laser } \\
\text { photocoagulation }\end{array}$ & $6 / 15$ & $2 / 21$ & 0.015 \\
\hline Mean follow-up time (weeks) & $20.2 \pm 4.7$ & $19.8 \pm 3.6$ & 0.970 \\
\hline Age at initial injection (weeks) & $34.4 \pm 1.0$ & $35.3 \pm 1.7$ & 0.830 \\
\hline
\end{tabular}


Plus disease (arterial tortuosity and venous dilation), formation of retinal neovascularization, and ROP stage regression was observed on the $3^{\text {rd }}$ day following intravitreal injection in group 2 patients and on the $7^{\text {th }}$ day in group 1 patients, except for one patient who received confluent laser photocoagulation during the first week.

Relapse following regression of plus disease was observed in 4 eyes of 2 patients from group 1 and 2 eyes of 1 patient from group 2 (Figure 3 ). Relapse was observed on the $8^{\text {th }}$ week in 2 patients from group 1 and $14^{\text {th }}$ week in 1 patient of group 2. One session of confluent laser photocoagulation was performed in both groups with relapse (Figure 4). The average age at the time of laser treatment was $41 \pm 3$ weeks in group 1 and 50 weeks in group 2 .

The mean follow-up duration was $20 \pm 4.5$ months (range, 12-27). No eyes developed retinal detachment during the follow-up period. Local complications secondary to treatment, such as retinal hemorrhage, tear, cataract formation and glaucoma, were not observed in any patients. Only subconjunctival hemorrhage was observed. Netilmicin eye drops were prescribed four times in a day for 10 days to all patients. This was not implemented as additional treatment. One patient from group 1 developed proteinuria and growth retardation of unknown cause.

\section{DISCUSSION}

An increase in VEGF levels is one of the main mechanisms underlying ROP development. The aim of laser photocoagulation is to decrease VEGF levels produced by the avascular retina by ablating the retinal periphery. Lately, anti-VEGF drugs have been used as monotherapy agents or in addition to laser photocoagulation, with successful results obtained ${ }^{(7-9,11-16)}$. The majority of studies have

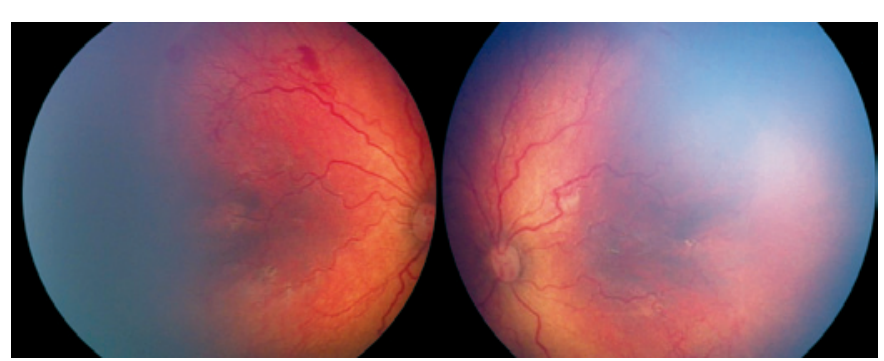

Figure 3. The ROP line is more evident with increases in vascular tortuosity observed, particularly in the right eye, 8 weeks after IV ranibizumab injection.

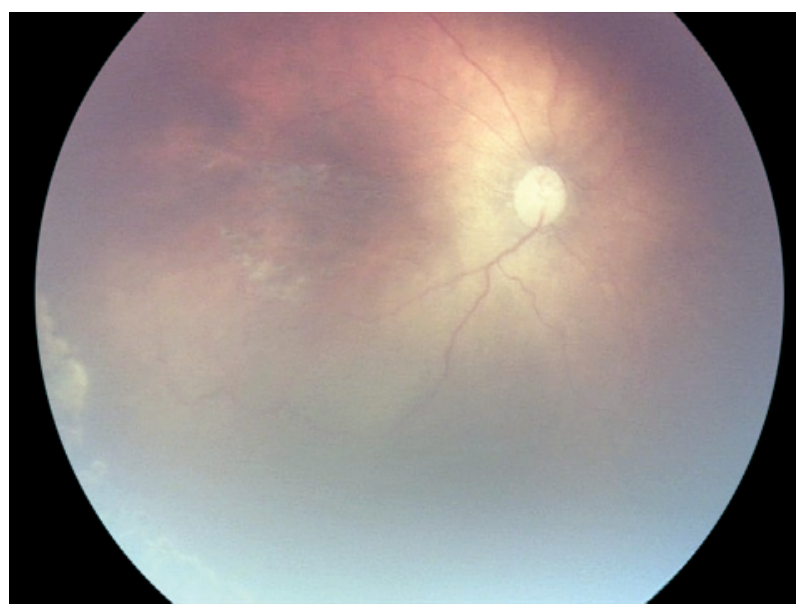

Figure 4. Fundus view of the same patient 3 months after laser photocoagulation. reported the results of bevacizumab therapy. There are a few case series presenting results with ranibizumab ${ }^{(7,8)}$. Although there are studies comparing the efficacy of ranibizumab and bevacizumab in patients with age-related macular degeneration, to the best of our knowledge, the present study is the first to compare their efficacy in patients with $\mathrm{ROP}^{(17)}$

In a prospective study, Mintz-Hittner et al. ${ }^{(18)}$ treated 22 eyes of 11 infants with stage 3 ROP in zone I or posterior zone II with bilateral intravitreal bevacizumab injection without laser photocoagulation. One injection was found to be sufficient, and normal retinal vascularization proceeded in all cases. Dorta et al.(19) also performed single intravitreal bevacizumab injection for the treatment of type 1 ROP in 12 eyes of 7 premature infants and demonstrated disease regression without additional treatment. Quiroz-Mercado et al. ${ }^{(20)}$ treated 18 eyes of 13 premature infants with a mean gestational age of 29 weeks and mean age at the time of the treatment of 38 weeks by single intravitreal bevacizumab injection. They observed regression of neovascularization in all eyes and reattachment of the retina in one eye with stage 4a ROP without systemic or ocular complications. Castellanos et al. ${ }^{(7)}$ treated 6 eyes with high-risk pre-threshold and threshold ROP disease by intravitreal ranibizumab without laser photocoagulation and demonstrated a single dose of intravitreal ranibizumab was sufficient to regress retinal neovascularization with no recurrences observed after a 3-year follow-up period.

Consistent with previous studies, the present study demonstrated that both ranibizumab and bevacizumab are effective in type 1 ROP treatment, with relapse rates higher with ranibizumab injections. The efficacy and reliability of these two agents in the treatment of age-related macular degeneration have previously been shown to be similar ${ }^{(17)}$. Different pharmacokinetic behavior in prematures whose organ development is not complete may contribute to the difference in relapse rates observed between the two drugs. In adults, the systemic half-life of ranibizumab is $2 \mathrm{~h}$, while the half-life of bevacizumab is up to 20 days because of the attachment of fragment crystallizable region (Fc region) to endothelial cells, thereby decreasing clearance ${ }^{(21)}$. However, the systemic pharmacokinetic properties of these two drugs in children have not to be fully elucidated.

In an animal study, the efficacy of bevacizumab in fellow eyes was apparently superior to ranibizumab in suppressing subretinal neovascularization in rats ${ }^{(22)}$. The efficacy of bevacizumab may have been doubled in the nine patients who received bilateral injections, which may have contributed to the low relapse rate in the present study. The lack of progression in fellow eyes may be associated with systemic effects of the anti-VEGF drugs.

Still, relapse following bevacizumab therapy has been reported. Jennifer et al. ${ }^{(23)}$ reported relapse in 17 eyes of 9 patients who received bevacizumab. The mean time to relapse was 14.4 weeks. One case of retinal detachment occurring 3 months after combined intravitreal ranibizumab injection and laser photocoagulation for zone 1 ROP with plus disease has been reported ${ }^{(24)}$. The time to relapse in the present case in the bevacizumab group was also 14 weeks. Relapse was seen in the 8th week in the ranibizumab group. Earlier relapse may be due to the shorter half-life of ranibizumab.

The risk of systemic complications is apparently higher after intravitreal bevacizumab injections compared to ranibizumab. In the present study, a patient was diagnosed with proteinuria in the ranibizumab group. The exact cause of proteinuria was not assessed. Proteinuria following ranibizumab injection may be incidental. However, nephropathy has previously been reported after intravitreal injections of both bevacizumab and ranibizumab for exudative agerelated macular degeneration ${ }^{(25,26)}$. Pelle et al. ${ }^{(26)}$ proposed excessive VEGF expression by podocytes in the normal kidney as the mechanism underlying proteinuria. Dysregulation of VEGF expression within the glomerulus has been associated with a wide range of renal diseases, many of which cause significant hypertension and varying amounts of proteinuria that may occur within weeks to months after administration intravitreal anti-VEGF therapy ${ }^{(25,26)}$. 
A number of previous studies have evaluated the utility of antiVEGF therapies in ROP; however, the optimal dosage and timing of injections remains under debate ${ }^{(23)}$. Although Avery claims that ranibizumab is a safer alternative to bevacizumab, complications may be seen following intravitreal administration ${ }^{(27)}$. Harder et al. ${ }^{(28)}$ obtained successful results with the use of $0.375 \mathrm{mg}$ bevacizumab, which is lower than the ROP dose. The results observed with bevacizumab in the present study may be attributable to the later time the injections, although this difference was not statistically significant.

The present study was limited by the retrospective design and the number of cases recruited. Moreover, the less precise criterion used for relapse than used for primary ROP was a further weakness.

Both ranibizumab and bevacizumab therapies showed an efficacy in the treatment of type 1 ROP treatment. Relapse rates were apparently less following bevacizumab injections compared to ranibizumab. Further randomized prospective studies with higher numbers of cases are required to validate the results of the present study.

\section{REFERENCES}

1. Gilbert C. Retinopathy of prematurity: a global perspective of the epidemics, popu lation of babies at risk and implications for control. Early Hum Dev. 2008;84(2):77-82.

2. Chawla D, Agarwal R, Deorari AK, Paul VK. Retinopathy of prematurity. Indian J Pediatr. 2008;75(1):73-6

3. Chen J, Smith LE. Retinopathy of prematurity. Angiogenesis. 2007;10(2):133-40.

4. Good WV; Early Treatment for Retinopathy of Prematurity Cooperative Group. Final results of the Early Treatment for Retinopathy of Prematurity (ETROP) randomized trial. Trans Am Ophthalmol Soc. 2004;102:233-48.

5. Villegas Becerril E, Gonzalez Fernández R, Fernández Molina F, Gallardo Galera JM. Growth factor levels and ROP. Ophthalmology. 2005;112(12):2238.

6. Mintz-Hittner HA, Kennedy KA, Chuang AZ; BEATROP Cooperative Group. Efficacy of intravitreal bevacizumab for stage 3+ retinopathy of prematurity. N Engl J Med. 2011;364(7)603-15. Comment in: N Engl J Med. 2011;364(24):2359; author reply 2361-2; N Engl J Med. 2011;364(7):677-8. N Engl J Med. 2011;364(24):2360; author reply 2361-2.

7. Castellanos MA, Schwartz S, García-Aguirre G, Quiroz-Mercado H. Short-term outcome after intravitreal ranibizumab injections for the treatment of retinopathy of prematurity. Br J Ophthalmol. 2013;97(7):816-9.

8. Mota A, Carneiro A, Breda J, Rosas V, Magalhães A, Silva R, et al. Combination of intravitreal ranibizumab and laser photocoagulation for aggressive posterior retinopathy of prematurity. Case Report Ophthalmol. 2012;3(1):136-41.

9. Autrata R, Krejcírová I, Senková K, Holoušová M, Doležel Z, Borek I. Intravitreal pegaptanib combined with diode laser therapy for stage $3+$ retinopathy of prematurity in zone I and posterior zone II. Eur J Ophthalmol. 2012;22(5):687-94.

10. International Committee for the Classification of Retinopathy of Prematurity. The International Classification of Retinopathy of Prematurity revisited. Arch Ophthalmol. 2005;123(7):991-9. Comment in: Arch Ophthalmol. 2006;124(11):1669-70.
11. Mintz-Hittner HA, Best LM. Antivascular endothelial growth factor for retinopathy of prematurity. Curr Opin Pediatr. 2009;21(2):182-7.

12. Chung EJ, Kim JH, Ahn HS, Koh HJ. Combination of laser photocoagulation and intravitreal bevacizumab (Avastin) for aggressive zone I retinopathy of prematurity. Graefes Arch Clin Exp Ophthalmol. 2007;245(11):1727-30.

13. Quiroz-Mercado H, Martinez-Castellanos MA, Hernandez- Rojas ML, Salazar-Teran N, Chan RV. Antiangiogenic therapy with intravitreal bevacizumab for retinopathy of prematurity. Retina. 2008;28(3 Suppl):S19-25.

14. Lee JY, Chae JB, Yang SJ, Yoon YH, Kim JG. Effects of intravitreal bevacizumab and laser in retinopathy of prematurity therapy on the development of peripheral retinal vessels. Graefes Arch Clin Exp Ophthalmol. 2010;248(9):1257-62.

15. Roohipoor R, Ghasemi H, Ghassemi F, Karkhaneh R, Riazi-Esfahani M, Nili-Ahmadabadi M. Intravitreal bevacizumab in retinopathy of prematurity: an interventional case series. Graefes Arch Clin Exp Ophthalmol. 2011;249(9):1295-301.

16. Erol MK, Coban DT, Özdemir Ö, Tunay ZÖ, Bilgin AB, Dogan B. Spectral-domain OCT Analyses of Macular Changes After Ranibizumab Therapy for Type 1 Retinopathy of Prematurity. J Pediatr Ophthalmol Strabismus. 2015;52(3):152-8.

17. CATT Research Group; Martin DF, Maguire MG, Ying GS, Grunwald JE, Fine SL, Jaffe GJ. Ranibizumab and bevacizumab for neovascular age-related macular degeneration. N Engl J Med. 2011;364(2):1897-908. Comment in: JAMA. 2014 ;311(15):1491-2. N Engl J Med. 2011;364(20):1966-7. N Engl J Med. 2011;365(23):2238. N Engl J Med. 2011; 365(23):2237; author reply 2237.

18. Mintz-Hittner HA, Kuffel RR. Intravitreal injection of bevacizumab (Avastin) for treatment of stage 3 retinopathy of prematurity in zone I or posterior zone II. Retina. 2008; 28(6):831-8.

19. Dorta P, Kychenthal A. Treatment of type 1 retinopathy of prematurity with intravitreal bevacizumab (Avastin). Retina. 2010;30(4 Suppl):S24-31.

20. Quiroz-Mercado H, Martinez-Castellanos MA, Hernandez- Rojas ML, Salazar-Teran N, Chan RV. Antiangiogenic therapy with intravitreal bevacizumab for retinopathy of prematurity. Retina. 2008;28( 3 Suppl):S19-S25.

21. Tolentino M. Systemic and ocular safety of intravitreal anti-VEG F therapies for ocular neovascular disease. Surv Ophthalmol. 2011;56(2):95-113.

22. Miki K, Miki A, Matsuoka M, Muramatsu D, Hackett SF, Campochiaro PA. Effects of intraocular ranibizumab and bevacizumab in transgenic mice expressing human vascular endothelial growth factor. Ophthalmology. 2009;116(9):1748-54.

23. Hu J, Blair MP, Shapiro MJ, Lichtenstein SJ, Galasso JM, Kapur R. Reactivation of retinopathy of prematurity after bevacizumab injection. Arch Ophthalmol. 2012; 130(8):1001-6. Erratum in: Arch Ophthalmol. 2013;13(2):212. Comment in: JAMA Ophthalmol. 2013;131(4):546-7. JAMA Ophthalmol. 2013;131(4):544-5.

24. Jang SY, Choi KS, Lee SJ. Delayed-onset retinal detachment after an intravitreal injection of ranibizumab for zone 1 plus retinopathy of prematurity. J AAPOS. 2010; 14:457-9.

25. Anto HR, Hyman GF, Li JP, Spitalewitz S, Thomas D. Membranous nephropathy following intravitreal injection of bevacizumab. Can J Ophthalmol. 2012;47(1):84-6.

26. Pellé G, Shweke N, Duong Van Huyen JP, Tricot L, Hessaine S, Frémeaux-Bacchi V, et al. Systemic and kidney toxicity of intraocular administration of vascular endothelial growth factor inhibitors. Am J Kid Dis. 2011;57(5):756-9.

27. Avery RL. Bevacizumab (Avastin) for retinopathy of prematurity: wrong dose, wrong drug, or both? J AAPOS. 2012;16(1):2-4.

28. Harder BC, von Baltz S, Jonas JB, Schlichtenbrede FC. Intravitreal low-dosage bevacizumab for retinopathy of prematurity. Acta Ophthalmol. 2014;92(6):577-81. 